CZU:94(498)"18"'(092)+398.8

https://doi.org/10.52505/filomod.2021.15.47

\title{
ПАМЯТЬ О ТУДОРЕ ВЛАДИМИРЕСКУ В ФОЛЬКЛОРНЫХ ТЕКСТАХ, СОБРАННЫХ ЗА ПРЕДЕЛАМИ ДУНАЙСКИХ КНЯЖЕСТВ
}

\author{
НАТАЛИЯ ГОЛАНТ, МАРИЯ РЫЖОВА \\ Музей антропологии и этнографии им. Петра Великого \\ (Кунсткамера) РАН, (Санкт-Петербург, Российская Федерачия)
}

\begin{abstract}
Резюме. Память о национальном герое Тудоре Владимиреску, имя которого мы вспоминаем спустя 200 лет со дня гибели, живет в народной поэзии. Статья посвящена вариантам исторических песен о Тудоре Владимиреску, зафиксированных на территориях, не входивиих в состав Дунайских княжеств - Валахии и Молдовы, и оставшихся за пределами Румынии в ее нынешних границах, однако входящих в зону распространения румынского языка. Это тексты, записанные на территории Бессарабии (нынешней Республики Молдова) и долины реки Тимок (в восточной Сербии, в исторической области Краина), известнь нам благодаря деятельности собирателей фольклора ХІХ и ХХ веков.
\end{abstract}

Ключевые слова: Революиия 1821 года, Валашское восстание, Тудор Владимиреску, фольклорные тексты.

Abstract. The memory of the national hero Tudor Vladimirescu, whose name is still commemorated 200 years after his death, is preserved in folk poetry. The article is devoted to versions of historical songs about Tudor Vladimirescu, recorded in the territories outside Danubian Principalities - Wallachia and Moldova, and also remained outside Romania in its current borders, but were included in the zone of distribution of the Romanian language. These texts, which were recorded in the territory of Bessarabia (present-day Republic of Moldova) and the valley of the Timok River (in eastern Serbia, in the historical region of Krajina), are known to us thanks to the activity of folklore collectors of the 19th and 20th centuries.

Keywords: the Revolution of 1821, the Wallachian Uprising, Tudor Vladimirescu, folklore texts.

Одним из источников памяти о национальном герое Тудоре Владимиреску, имя которого мы вспоминаем спустя 200 лет со дня гибели, представляет собой народная поэзия. Румынская эпическая поэзия сформировалась задолго до начала её письменной фиксации, процесс которой начался преимущественно в 19 веке. Еще в 16 веке Матвей Стрыйковский в своией «Хронике» отмечал, что в Дунайских княжествах можно услышать песни, «прославляющие подвиги павших 
мужей...» (Гацак, с. 3), этот издавна бытующий обычай засвидетельствует и Николае Костин в «Летописи Молдавского Государства от сотворения мира до 1601 г.»: «(...) Ардяле и здесь, у нас в стране и сегодня (...) лаутары поют песни о господарях давнего времени с похвалою хорошим и осуждением злых и лютых» (Costin, с.42).

В традициях румынской исторической песни в народе были сложены многочисленные фольклорные песни, посвященные Тудору Владимиреску, возглавившему румынское национально-крестьянское восстание, определившее судьбу греческой революции 1821 года в придунайских землях.

Как известно, во время русско-турецкой войны 1806-1812 годов в войсках господаря Константина Ипсиланти, входивших в состав русской армии отдельный корпус добровольцев был образован из крестьянских ополченцев, жителей Малой Валахии (Олтении), называемых «пандурами», которые показали свои отличные воинские качества во время этой войны. Задача пандур заключалась в очистке Олтении от турецких формирований и недопущении их прорыва в дальнейшем. В кампанию 1808 года пандуры переправились на правый берег Дуная и участвовали в осаде Видина, в сражениях под Раховым и Неготином. Именно из этой среды выдвинулся отважный воин Тудор Владимиреску, уроженец Олтении, села Владимир(ь), уезда Мехединц волости Клошань, которому вверено было командование всем корпусом пандуров. Он был награжден орденом св. Владимира и произведен в чин поручика. После окончания войны Владимиреску отправился в Австрию, где познакомился с идеями французской революции. Там же произошла его первая встреча с этеристами. Вернувшись в ноябре 1820 г. в Бухарест, Тудор поселился в доме боярина Константина Самуркаша, в котором этеристы проводили совещания. Тогда же он и поклялся добиваться «вооруженным путем освобождения от варваров и возрождения победоносного креста» (Виноградов, с. 410 -412, 421). 15 января 1821 г. три члена временного политического органа под названием Управленческий комитет, представители крупного боярства Григоре Брынковяну, Григоре Гика и Барбу Вэкэреску поручили Тудору Владимиреску поднять «вооруженный народ» на восстание с целью свержения османской власти (Болован, с. 419, Виноградов, с. 421). Однако восстание рассматривалось им не только как движение, направленное исключительно против турок, как это видно из его прокламаций и писем, но и против господарейфанариотов и их прислужников но и против господарей-фанариотов и их прислужников из среды бояр, и это придавало его восстанию характер социальной революции (C.D. Ariscescu, p. 27, 28, 52-54, 121, 122, 128, 129-131). Не случайно события 1821 года и трагическая гибель Тудора Владимиреску на берегу Дымбовицы в городе Тырговиште, оставили глубокий след в памяти народа. По словам И. П. Липранди, «убийство это было поводом сложения народной, на валахском языке, песни, распространившейся не только в обоих Валахиях, но и в Молдавии, откуда перешла и в Бессарабию. Она слышалась повсюду, и, напев её, 
столь же оригинальный, как и сложение, слышался по улицам и часто не только у простолюдинов, но и более в высших чинах (...). Печальные слова раздавались со всех сторон» [Мясоедова, 162]. Песни, сложенные о Тудоре в Дунайских княжествах, распространились за их пределами. Эта песня, в которой в аллегорических выражениях говорится о трагической судьбе Владимиреску, звучавшая на улицах города и в домах бояр в исполнении цыганских хоров, привлекла к себе внимание А.С. Пушкина в бытность его в Кишиневе (Двойченко-Маркова, с. 406).

Иван Петрович Липранди в своем дневнике писал о литературном наследии Пушкина: «...мне удивительно, что я не встретил в помянутом исчислении двух современных исторических, народом сложенных песен, которые, как мне близко известно, в особенности занимали. Куплеты из этих песен беспрерывно слышны были на всех улицах, а равно исполнялись и хорами цыганских музыкантов. Кто из бывших тогда в Бессарабии и особенно в Кишиневе не помнит беспрерывных повторений: „Пом, пом, пом помиерами, пом“ и „фронзе верде (шалала), Савва Бим-баша?“ Первая из них сложена аллегорически на предательское умерщвление главы пандурского восстания Тодора Владимирески, по распоряжению князя Ипсиланти в окрестностях Тырговиста... Александр Сергеевич имел перевод этих песен; он приносил их ко мне, с тем, чтобы поверить со слов моего арнаута Георгия. Но в декабре 1823 года, бывши в Одессе, Пушкин сказал мне, что он не знает, куда девались у него эти песни, и просил, чтобы я доставил ему копию с своего перевода; в январе 1824 года, опять приехавши в Одессу, я ему их передал» [Липранди, Стлб 1407-1408].

Текст песни под названием "Народная песня, составленная в 1821 г. по случаю восстания Пандур под предводительством Тодора Владимирески по убийстве его" вместе с текстом "Народной песни, преимущественно между арнаутами, на убийство Бимбаши Саввы” был обнаружен в 1954 г. среди различных материалов, входящих в состав фонда Ивана Петровича Липранди в Центральном государственном историческом архиве СССР (ныне РГИА) в Ленинграде исследователем Макаром Павловичем Легавкой. Тексты этих песен впервые были опубликованы и прокомментированы в статье Ефросиньи Михайловны Двойченко-Марковой «Пушкин и румынская народная песня о Тудоре Владимиреску», вышедшей в сборнике «Пушкин. Исследования и материалы» в 1960 г. (Двойченко-Маркова, с. 412 - 413).

Вариант, сохранившийся в архиве Липранди отличается от известных нам песен о Тудоре Владимиреску, дошедших до нас благодаря собирателям фольклорных текстов 19 века Василе Александри и Георге Дем Теодореску. Не удалось нам обнаружить этот или подобный текст и в других сборниках румынского фольклора. Лишь в сборнике «Folclorul român din Basarabia» (авторы - собиратели народного фолклора, Татьяна Гэлушкэ и Иоан Никола) обратила на себя внимание одна песня, состоящая всего из 8 строк, слова которой схожи с фрагментом текста рукописи. Записана она была на слух («с голоса») в 1938 году в 
Молдавском селе Крэкэнич [Gălușcă, Nicola, p. 172]. Несмотря на то, что в ней нет упоминания о Тудоре Владимиреску, мы можем предположить, что изначально она была сложена в честь этого героя. Кроме того, интерес представляют и ноты к этому фрагменту, представленные в сборнике, тогда как в пометах к тексту песни, записанной Липранди было лишь упоминание о нотах, но нот самих обнаружено не было. Тем не менее, мелодия могла сыграть немаловажную роль в том, что поэт обратил внимание на песню, ведь как говорил сам Александр Сергеевич: «...Из наслаждений жизни одной любви музыка уступает; но и любовь мелодия...» (Мясоедова, с.164)

Текст из архива Липранди был записан кириллицей, очевидно, что Липранди записывал текст на слух, не вдаваясь в правила румынского языка. Так, в тексте практически отсутствуют знаки препинания, часто встречается слияние нескольких слов в одно, например, слова: «помераме», в котором угадывается сразу три слова «рот»- «дерево», «eram» - глагол «быть» (,a fi”) в имперфекте, в форме первого лица единственного числа и местоимение первого лица единственного числа «еu». Слово «миссоперде», по нашему представлению состоит из краткой формы личного местоимения в дательном падеже (т. н. «дательный притяжательный») «-ті», и глагола «se pierde»- «теряться» в 3 л. ед. ч. В слове «омирами», также как и в первом примере, мы можем предположить слияние трех слов «ом»- «человек», «еram» и «еu». Также встретились примеры неправильной разбивки слов, например, в начале первой песни две части «на инте» следует читать «і̂nainte» «вперед». Форма слов «витур бурата», вероятно, представляют собой с одной стороны слияние, с другой - разбивку двух слов: «ви», то есть «vii», форма 2 л.ед.ч. настоящего времени глагола «а veni» «приходить» (2 л.ед.ч.) и прилагательное «turburată» - «мутная».

Этоттекстпесни, несмотрянато, чтотакиосталсянеосуществленным замыслом А. С. Пушкина, имеет значение не только для исследователей пушкинского наследия, но и для исследователей румынского фольклора, так как является одним из первых зафиксированных на письме известных нам текстов песен о Тудоре Владимиреску.

Некоторую схожесть обнаруживает также фрагмент песни о Тудоре Владимиреску, которая содержится в собрании фольклорных текстов жителей долины реки Тимок «Народные песни румын Сербии», вышедшем под авторством французского филолога-романиста Эмиля Пико в 1889 г. В сборник вошли песни, которые сербский филолог, историк и дипломат Стоян Новакович (в то время - сербский посол в Стамбуле, который позже станет, председателем Сербской академии наук и искусств) собирал для Эмиля Пико с 1878 по 1880 г. (Picot, c. $7,71,72)$. Несмотря на то, что этот текст, очевидно, представляет собой лишь фрагмент песни, сохранившийся в памяти романоязычного населения восточной Сербии, он является подтверждением популярности национального героя, прославившегося в этих краях вместе с отрядами пандур задолго до событий 1821 года. 
В случае с текстом, зафиксированном на территории Республики Молдовы в 1938 г. и опубликованном в сборнике Татьяны Гэлушкэ и Иона Николы, некоторая схожесть обнаружилась с фрагментом, где используется междометие «hаi», имеющее четко выраженную семантическую функцию побуждения к действию (движения вперед): "Hai, hai, inimă, hai! / Hai, inimă, mai la vali (...). В случае текста из сборника Николя Пико, схожесть с текстом Липранди видна во фрагменте, где используется глагол «fi» (быть) в повелительном наклонении. Кроме того, все три текста объединяет тема обращения к «сердцу» (Fi inima, fi / hai, inima, hai).

Еще один текст песни о Тудоре Владимиреску был записан Кристей Санду Тимоком, известным собирателем румынского фольклора долины реки Тимок, в 1939 г. в с. Ковилово (рум. Coilova) нынешней общины Борского округа в восточной Сербии от информанта по имени Кирин Пени (Chirin Peni), которому на тот момент было 40 лет. Этот текст был включен в сборник "Căntece bătrâneşti şi doine", который Санду Тимок опубликовал в 1967 г. в Бухаресте. Он отличается от приведенных выше текстов прежде всего характером повествования. «Историческая песня» «Domnul Tudor Țăreanu», как определяет её сам автор сборника, без сомнения посвящена Тудору Владимиреску, хотя в тексте не упоминается фамилия главного героя. Слово „Domnul” в названии песни отражает данное Тудору Владимиреску в народе прозвание „Domnul Tudor” (т.е. «господарь Тудор»), которое появилось благодаря тому факту, что весной 1821 г. он захватил Бухарест и с марта по май был фактическим правителем Валахии. Имя Tudor Țăreanu можно перевести как «Тудор крестьянин», если опираться на данные стандартного румынского языка, однако в говорах долины Тимока слово ţărean (pl. țăreni) употребляется в значении «носителель олтенского говора румынского языка», т.е. фактически в качестве этнонима, тогда как в значении «крестьянин» чаще употребляется слово "sătean". Нужно отметить, что село Ковилово, где был записан этот текст, относится как раз к зоне олтенских (или так называемых «царанских») говоров. На то, что речь в песне идет именно о Тудоре Владимиреску, указывает сюжет повествования и приводимые в нем факты: в тексте говорится о том, что Тудор получил военную подготовку в русской армии, о том, что он был олтянином, о том, что греки взяли его в плен, а затем убили, и о том, каким именно образом они это сделали (Tudorel este voinic, de rus este instruit / Tudorel este oltean, n-are teamă de dușman; L-au prins grecii în namiaz (...) După aia 1-au tăiat, trupu i l-au înecat (...). Упоминания о движении пандуров, о господаре фанариоте Ионе Георге Караджа и др. также подтверждают личность героя песни. Национально-освободительный характер борьбы, возглавляемой Тудором Владимиреску, подчеркивается строками о том, что его желанием было освободить страну (Валахию) и защищать румын (Vrea ţara s-o dezrobească / Pe rumâni să mi-i păzească). Впрочем, жесткого противопоставления румын грекам и туркам в тексте нет (хотя 
греки упоминаются в качестве убийц Тудора, а турки представлены неким «Рушид-пашой из Видина», который пишет султану о том, что Тудор взойдет на трон до следующего года). Основное внимание в тексте уделено борьбе Тудора с «чокоями» (боярами, богачами), т.е. во главу угла ставится социальный аспект. Эта песня, наряду с упомянутыми выше, также представляет интерес как для изучения исторических песен в целом, так и песен, сложенных в честь Тудора Владимиреску.

Представленные нами исторические песни, зафиксированные на территориях, граничащих с современной Румынией, во многом отличаются от таких известных ныне исторических песен, как «Сон Тудора» (Visul lui Tudor), и дойна «Мехединец» (Mehedințeanul), опубликованные Василе Александри и «Песня пандуров 1921 года» (Cântecul pandurilor din 1821), опубликованная Г. Дем. Теодореску.

\section{Литература и источники}

1. ARISCESCU C. D. Acte justificative la istoria Revoluțiunii Române de la 1821. Editura typographiei române G. Chitiu și I. Theodorian. Craiova, 1874.

2. Cântece bătrânești ale românilor. Cântece istorice. Colecție inițiată și coordonată de A. Vidrașcu și Dan Vidrașcu. Editia a II-a. București, Chișinău, 2003.

3. COSTIN, N. Letopiseţul Tăriii Moldóvei de la zidirea lumiả până la 1601. Ediție îngrijită de Ioan Șt. Petre. români vechi, Fundaţia Regală pentru Literatură şi Artă. Bucureşti, 1942.

4. Flori alese din poezia populară, I, Poezia lirică, Ediție îngrijită de Ioan Șerb, pref. de Mihai Pop. București, 1967.

5. GÂLUȘCÂ T., NICOLA I. Folclor român din Basarabia. Î.E.P. Știința. Chișinău, 1999.

6. GEORGESCU I. Istoria lui Tudor Vladimirescu // Biblioteca poporală a „Asociațiunei”. Publicațiune periodică lunară. Editura „Asociațiunei”. Sibiu, Martie 1931.

7. PICOT M. E. Chants populaires des roumains de Serbie. Paris, Imprimerie nationale. Ernest Leroux, éditeur, rue Bonaparte, 28, 1889.

8. SANDU TIMOC C. Cîntece bătrâneşti şi doine. București: Editura pentru literatură, 1967. ВИНОГРАДОВ В. Н. Тудор Владимиреску // Исторические nортреты. Народы Юго-Восточной Европы. Конеи XVIII - середина XIX в. Алетейя.. Историческая книга. Санкт-Петербург, 2012. С. 409-435.

9. ГАЦАК В. М. Тайны народного эпоса // Румынская народная поэзия. M., 1987. C. 3-20.

10. ДВОЙЧЕНКО-МАРКОВА Е. М., Пушкин и румынская народная песня о Тудоре Владимиреску. В кн.: Пушкин. Исследования и материальы. Изд. АН СССР, М. - Л., 1960, С.402-417;

11. ЛЕГАВКА М. П., Два документа периода кишиневской ссылки А. С. Пушикина // От «Слова о полку Игореве» до «Тихого Дона». Институт русской литературы (Пушкинский дом) "Наука, " Ленингр. отд-ние, 1969. С. 305-316.

12. ЛИПРАНДИ И. П. Из дневника и воспоминаний. Заметки на статью: Пушкин в Южной России // Русский архив. М., 1866. № 8-9. Стлб 1393-1491.

13. МЯСОЕДОВА Н. Е. Пушикинские замысслье. РАН, Институт русской литературы (Пушкинский дом). СПб, 2002. 